\title{
ANALISIS GAYA KEPEMIMPINAN PADA KANTOR CAMAT ASAKOTA KOTA BIMA
}

\author{
Febi Astriani ${ }^{*}$, Ita Purnama **) \\ Email : ita123purnama@gmail.com
}

\begin{abstract}
ABSTRAK
Penelitian ini bertujuan untuk mengetahui dan menganalisis bagaimanakah gaya kepemimpinan pada Kantor Camat Asakota Kota Bima. Jenis penelitian yang digunakan adalah penelitian deskriptif, dengan sampel penelitian sebanyak 52 orang responden. Teknik sampling yang digunakan adalah sampling jenuh. Pengumpulan data menggunakan observasi, kuisioner, wawancara dan studi pusaka. Metode analisis data yang digunakan adalah uji t-test one sampel dan juga dengan menggunakan program SPSS. Hasil dari penelitian ini menyimpulkan bahwa gaya kepemimpinan pada Kantor Camat Asakota Kota Bima lebih dari atau sama dengan $70 \%$ dari yang diharapkan (baik) yang dibuktikan dengan nilai uji t sebesar 107,364 dan Sig 0,000. Jika di bandingkan antara nilai t hitung dengan $t$ tabel maka t hitung lebih besar dari t tabel $(19,850>1,679)$, dan nilai Sig $<0,05(0,000<0,05)$ artinya signifikan sehingga $\mathrm{H}_{\mathrm{a}}$ diterima dan $\mathrm{H}_{0}$ ditolak.
\end{abstract}

Kata Kunci : Gaya Kepemimpinan

\begin{abstract}
This study aims to determine and analyze how the leadership style of the City of Bima Asakota District Office. This type of research is a descriptive study, with a sample of 52 respondents. The sampling technique used is saturation sampling. Data collection uses observations, questionnaires, interviews and heritage studies. The data analysis method used is the one sample t-test and also using the SPSS program. The results of this study concluded that the leadership style at the Bima Asakota Sub-district Office was more than or equal to $70 \%$ of the expected (good) as evidenced by the $t$ test value of 107,364 and Sig 0,000 . If compared between the value of $t$ arithmetic with $t$ table then $t$ arithmetic is greater than $t$ table $(19,850>1,679)$, and the value of Sig $<0.05(0,000<0.05)$ means that it is significant so that $\mathrm{Ha}$ is accepted and $\mathrm{HO}$ is rejected.
\end{abstract}

Keywords: Leadership Style

$\left.{ }^{*}\right) \&^{* *}$ ) Sekolah Tinggi Ilmu Ekonomi Bima 


\section{PENDAHULUAN}

Djumhariati (2008:46) mengemukakan bahwa didalam sebuah organisasi, sumber daya manusia merupakan aset yang paling penting dalam keberhasilan membangun budaya organisasi. Oleh karena itu, sumber daya manusia merupakan penentu berhasil atau tidaknya tujuan organisasi yang akan dicapai. Budaya organisasi yang kuat merupakan kunci kesuksesan dari sebuah organisasi, baik itu organisasi pemerintahan maupun swasta. Untuk menjamin tercapainya tujuan organisasi yang telah disusun, maka diperlukan pemimpin yang bertugas secara terus menerus memelihara dan mengembangkan organisasi secara struktural, ideal, dan fungsional sehingga dapat mencapai tujuan organisasi yang telah ditetapkan.

Kepemimpinan merupakan salah satu topik yang selalu menarik untuk dibahas. Kepemimpinan dipengaruhi oleh seorang pemimpin dalam mengelola organisasinya. Kepemimpinan berkaitan dengan proses yang disengaja dari seseorang untuk menekankan pengaruhnya kepada orang lain. Pemimpin dan karyawan merupakan bagian dari sumber daya manusia. Sumber daya manusia merupakan elemen utama organisasi dibandingkan dengan elemen lain seperti modal, teknologi dan uang. Sumber daya manusia merupakan pelaksana dalam perusahaan yang akan mengelola dan memanfaatkan elemen tersebut. Elemen-elemen tersebut harus dapat dikelola dan dimanfaatkan secara efektif dan efisien. Sumber daya manusia menjadi unsur yang paling penting dalam setiap aktivitas yang dilakukan di perusahaan. Modal, teknologi dan uang tidak akan berguna tanpa peran aktif dari sumber daya manusia yang mengelolanya.

Pemimpin merupakan sumber daya manusia yang paling berpengaruh di dalam setiap organisasi bisnis. Menurut Bangun (2012 : 339), kepemimpinan merupakan proses mempengaruhi orang lain dalam suatu organisasi untuk melaksanakan tugasnya dengan baik agar tercapainya tujuan perusahaan. Dalam hal ini karyawan wajib dan terkait untuk mengerjakan pekerjaan yang diberikan pimpinan. Karyawan di perusahaan bertugas sebagai pelaksana operasional perusahaan, sedangkan pimpinan merupakan orang yang bertanggung jawab dalam mengarahkan jalannya operasional perusahaan.

Kepemimpinan memegang peranan yang sangat penting dalam pencapaian keberhasilan sebuah organisasi dikarenakan mampu mempengaruhi kinerja dari organisasi tersebut. Kepemimpinan yang efektif harus mampu berperan menjadi sosok dari budaya yang dibangunnya, karena pemimpim merupakan orang dengan motivasi tinggi dalam memimpin dan mengendalikan organisasi dan berusaha untuk mencapai sasaran dan target yang tinggi dengan menetapkan standar-standar prestasi yang tinggi bagi mereka sendiri. Salah satu fungsi kepemimpinan adalah untuk mengajak, menghimbau semua bawahan agar dengan penuh kemauan memberikan pengabdian dalam mencapai tujuan budaya organisasi sesuai dengan kemampuan para bawahan secara maksimal. Kepemimpinan dapat dikatakan sebagai salah satu faktor penentu dalam kesuksesan atau gagalnya suatu organisasi. Sebab pemimpin yang sukses mampu mengelola organisasi, bisa mempengaruhi orang lain, dan menentukan jalan serta memberikan perilaku benar yang harus dikerjakan bersama-sama.

Kantor Camat Asakota Kota Bima adalah salah satu ujung tombak pelaksanaan pelayanan pemerintahan di Kecamatan yang terletak di Ule meski begitu ada beberapa hal yang masih menjadi kendala terkait gaya kepemimpinan di Kantor Camat Asakota 
diantaranya tidak tegassnya Camat Asakota dalam meberikan sanksi/hukuman bagi pegawainya yang malas bekerja, peran kepemimpinan dalam menciptakan komunikasi yang harmonis antara sesama pegawai masih kurang, minimnya pemberian pembinaan terhadap pegawai yang bermasalah atau kurang disipin dalam bekerja sehingga akan menyebabkan tingkat kinerja pegawai menjadi rendah.

Beberapa permasalahan yang timbul diatas membuat peneliti tertarik untuk mengangkatnya sebagai bentuk penelitian yang berjudul : "Analisis Gaya Kepemimpinan Pada Kantor Camat Asakota Kota Bima"

\section{TINJAUAN PUSTAKA}

\section{A. Manajemen Sumber Daya Manusia}

Menurut Wahyudi (2012), Manajemen sumber daya manusia adalah perencanaan, pengorganisasian, pengarahan, dan pengawasan daripada pengadaan, pengembangan, pemberian balas jasa, pengintegrasian, pemeliharaan dan pemisahan sumber daya manusia ke suatu titik akhir dimana tujuan-tujuan perorangan dan masyarakat terpenuhi.

Manajemen Sumber Daya Manusia memiliki peran penting untuk memberdayakan, mengembangkan, dan mempertahankan karyawan dalam perusahaan agar mampu memberikan kontribusi secara optimal terhadap pencapaian tujuan perusahaan berdasarkan keahlian, pengetahuan, dan kemampuan yang dimiliki.

Manajemen sumber daya manusia apabila dilaksanakan dengan baik akan memberikan kontribusi yang besar dalam usaha mencapai sasaran organisasi karena setiap perusahaan memerlukan sumber daya untuk mencapai tujuannya, sumber daya manusia merupakan energi, tenaga, kekuatan (power) yang diperlukan untuk menciptakan daya, gerakan, aktivitas, dan tindakan.

\section{B. Gaya Kepemimpinan}

Setiap pemimpin pada dasarnya memiliki perilaku yang berbeda dalam memimpin para bawahannya, perilaku para pemimpin itu disebut dengan gaya kepemimpinan. Gaya kepemimpinan merupakan suatu cara pemimpin untuk mempengaruhi bawahannya yang dinyatakan dalam bentuk pola tingkah laku atau kepribadian. Dalam era lama gaya kepemimpinan diartikan sebagai gaya kemampuan dan kesiapan yang dimiliki seseorang untuk mempengaruhi orang lain, dengan memotivasi, menggerakkan, mengarahkan, mengajak, menuntun dan jika perlu memaksa mereka untuk melakukan atau tidak melakukan sesuatu. Dalam era baru gaya kepemimpinan diartikan secara lebih luas, bukan sekedar kemampuan mempengaruhi, yang lebih penting adalah kemampuan memberi inspirasi kepada pihak lain, agar mereka secara proaktif tergugah untuk melakukan berbagai tindakan demi tercapainya visi, misi dan tujuan organisasi.

Menurut Waridin dan Bambang Guritno (2005), Gaya kepemimpinan adalah pola tingkah laku yang dirancang sedemikian rupa untuk mempengaruhi bawahannya agar dapat memaksimalkan kinerja yang dimiliki bawahannya sehingga kinerja organisasi dan tujuan organisasi dapat dimaksimalkan. Seorang pemimpin harus menerapkan gaya kepemimpinan untuk mengelola bawahannya, karena seorang pemimpin akan sangat mempengaruhi keberhasilan organisasi dalam mencapai tujuannya. 
Sedangkan menurut Tjiptono (2006:161) gaya kepemimpinan adalah suatu cara yang digunakan pemimpin dalam berinteraksi dengan bawahannya. Sementara itu, pendapat lain menyebutkan bahwa gaya kepemimpinan adalah pola tingkah laku (kata-kata dan tindakantindakan) dari seorang pemimpin yang dirasakan oleh orang lain (Robbins, 2012:429).

\section{Tipe-tipe Kepemimpinan}

Menurut Robbins (2012:431), gaya kepemimpinan sering disebut juga dengan tipe Kepemimpinan. Tipe kepemimpinan yang luas dikenal dan diakui keberadaanya adalah sebagai berikut :

\section{Tipe Otokratik}

Tipe kepemimpinan ini menganggap bahwa kepemimpinan adalah hak pribadinya (pemimpin), sehingga ia tidak perlu berkonsultasi dengan orang lain dan tidak boleh ada orang lain yang turut campur. Seorang pemimpin yang tergolong otokratik memiliki serangkaian karateristik yang biasanya dipandang sebagai karakteristik yang negatif. Seorang pemimpin otokratik adalah seorang yang egois. Seorang pemimpin otokratik akan menunjukan sikap yang menonjolakan keakuannya, dan selalu mengabaikan peranan bawahan dalam proses pengambilan keputusan, tidak mau menerima saran dan pandangan bawahannya.

2. Tipe Kendali Bebas atau Masa Bodo (Laisez Faire)

Tipe kepemimpinan ini merupakan kebalikan dari tipe kepemimpinan otokratik. Dalam kepemimpinan tipe ini sang pemimpin biasanya menunjukkan perilaku yang pasif dan seringkali menghindar diri dari tanggung jawab. Seorang pemimpin yang kendali bebas cenderung memilih peran yang pasif dan membiarkan organisasi berjalan menurut temponya sendiri. Disini seorang pemimpin mempunyai keyakinan bebas dengan memberikan kebebasan yang seluas-luasnya terhadap bawahan maka semua usahanya akan cepat berhasil.

3. Tipe Paternalistik

Persepsi seorang pemimpin yang paternalistik tentang peranannya dalam kehidupan organisasi dapat dikatakan diwarnai oleh harapan bawahan kepadanya. Harapan bawahan berwujud keinginan agar pemimpin mampu berperan sebagai bapak yang bersifat melindungi dan layak dijadikan sebagai tempat bertanya dan untuk memperoleh petunjuk, memberikan perhatian terhadap kepentingan dan kesejahteraan bawahannya. Pemimpin yang paternalistik mengharapkan agar legitimasi kepemimpinannya merupakan penerimaan atas peranannya yang dominan dalam kehidupan organisasi.

\section{Tipe Kharismatik}

Seorang pemimpin yang kharismatik memiliki karakteristik khusus yaitu daya tariknya yang sangat memikat, sehingga mampu memperoleh pengikut yang sangat besar dan para pengikutnya tidak selalu dapat menjelaskan secara konkrit mengapa orang tersebut itu dikagumi. Hingga sekarang, para ahli belum berhasil menemukan sebab-sebab mengapa seorang pemimpinmemiliki kharisma. Yang diketahui ialah bahwa pemimpin yang demikian mempunyai daya penarik yang amat besar. 
5. Tipe Militeristik

Pemimpin tipe militeristik berbeda dengan seorang pemimpin organisasi militer. Pemimpin yang bertipe militeristik ialah pemimpin dalam menggerakan bawahannya lebih sering mempergunakan sistem perintah, senang bergantung kepada pangkat dan jabatannya, dan senang kepada formalitas yang berlebih-lebihan.

\section{Indikator Gaya Kepemimpinan}

Robbins (2012 : 448) mengidentifikasikan empat gaya kepemimpinan yang dibedakan sebagai berikut :

1. Kepemimpinan direktif

Menurut Robbins (2012:448) kepemimpinan direktif yaitu gaya kepemimpinan yang mempunyai hubungan yang positif dengan kepuasan dan harapan bawahan. Atasan sering memberikan perintah atau tugas khusus (otokrasi). Sedangkan Davis dan Newstrom (2012:164) menyatakan kepemimpinan direktif adalah pemimpin yang memusatkan kuasa dan pengambilan keputusan bagi dirinya sendiri, pemimpin menata situasi kerja ynag rumit bagi para pegawai, yang melakukan apa saja yang diperintahkannya. Pemimpin berwenang penuh dan memikul tanggung jawab sepenuhnya. Pemimpin yang mempunyai gaya seperti ini pada umumnya sering memberikan perintah atau tugas khusus pada bawahannya, membuat keputusankeputusan penting dan banyak terlibat dalam pelaksanaanya. Semua kegiatan terpusat pada pemimpin. Pada dasarnya gaya direktif adalah gaya otoriter.

2. Kepemimpinan suportif

Menurut Robbins (2012:448) kepemimpinan suportif, yaitu kepemimpinan yang selalu bersedia menjelaskan segala permasalahan pada bawahan, mudah didekati dan memuaskan hati para karyawan. Sedangkan menurut Winardi (2000:63) menyatakan kepemimpinan suportif adalah pemimpin yang menciptakan suatu lingkungan kerja yang membantu mempertebal keinginan pada setiap pengikut untuk melaksanakan pekerjaan sebaik mungkin, bekerjasama dengan pihak lain, serta mengembangkan skillnya dan keinginannya sendiri.

Kepemimpinan suportif juga dikenal dengan istilah perilaku penyokong atau perhatian, dalam gaya ini pemimpin bersedia menjelaskan segala permasalahan pada bawahan, mudah didekati dan memuaskan kinerja para karyawan. dengan cara membimbing pengikut atau karyawan dengan sebaik-baiknya, menciptakan suatu lingkungan kerja yang membantu keinginan pada setiap pengikut untuk melaksanakan pekerjaan sebaik mungkin, bekerjasama dengan pihak lain, serta mengembangkan skillnya dan keinginannya sendiri.

3. Kepemimpinan partisipatif

Menurut Robbins (2012:448) kepemimpinan partisipatif adalah gaya kepemimpinan yang meminta dan menggunakan saran-saran bawahan dalam rangka mengambil keputusan. Sedangkan menurut Nawawi (2013:91) gaya kepemimpinan ini ditujukan dengan memberikan kesempatan pada anggota organisasi atau bawahan ikut serta dalam menetapkan tujuan, membuat keputusan dan mendiskripsikan perintah. 
Menurut pendapat tokoh-tokoh tersebut dalam gaya ini pemimpin cenderung meminta pendapat karyawan dan menggunakan saran serta gagasannya sebelum mengambil keputusan dan menggunakan metode karyawan tersebut terhadap pemecahan masalah dan mengambil keputusan tersebut jika dianggap sesuai oleh pemimpin. Selain itu pemimpin juga memberikan pada karyawan ikut serta dalam menetapkan tujuan, membuat keputusan dan mendiskripsikan perintah.

4. Kepemimpinan yang berorientasi pada prestasi.

Menurut Robbins (2012:448) kepemimpinan yang berorientasi prestasi, yaitu kepemimpinan yang mengajukan tantangan yang menarik bagi bawahan dan merangsang untuk mencapai tujuan, serta melaksanakan dengan baik. Makin tinggi orientasi pemimpin akan prestasi, maka makin banyak bawahan yang percaya akan menghasilkan pelaksanaan kerja yang efektif.

Menurut pendapat tokoh tersebut dalam gaya ini menetapkan tujuan yang menantang dan merangsang para karyawan, mengharapkan karyawan untuk berprestasi setinggi mungkin, percaya pada kemampuan karyawan untuk mencapainya, dan terus menerus mencari peningkatan hasil karya atau kerja

Untuk memberikan gambaran tentang penelitian ini maka penulis menyajikan dalam bentuk sebuah bagan yang berisi tentang arah hubungan antara variabel penelitian seperti berikut ini :

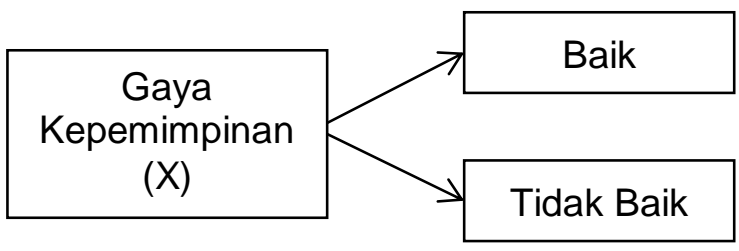

Adapun hipotesis yang diajukan dalam penelitian ini adalah :

Ho ; $\mu<70 \%$, Gaya Kepemimpinan pada Kantor Camat Asakota Kota Bima kurang dari 70\% dari yang diharapkan (Tidak Baik).

$\mathrm{Ha} ; \mu \geq 70 \%$, Gaya Kepemimpinan pada Kantor Camat Asakota Kota Bima lebih dari atau sama dengan $70 \%$ dari yang diharapkan (Baik).

\section{METODE PENELITIAN}

\section{A. Jenis Penelitian}

Dalam penelitian ini digunakan jenis penelitian deskriptif. Penelitian deskriptif adalah penelitian yang digunakan untuk mengetahui nilai variabel mandiri, baik satu variabel atau lebih (independen) tanpa membuat perbandingan, atau menghubungkan antara variabel satu dengan variabel yang lain (Sugiyono, 2016).

\section{B. Instrumen Penelitian}

Instrumen penelitian yang digunakan yaitu Kuisioner yang berisi sejumlah pertanyaan dengan pengukuran skala likert, dimana setiap pernyataan memiliki bobot penilaian yang berbeda. 


\section{Populasi Dan Sampel Penelitian}

Populasi yang digunakan yaitu seluruh pegawai pada Kantor Camar Asakota Kota Bima sebanyak 52 orang yang terdiri dari 19 orang PNS dan 33 orang tenaga kontrak dan sukarela.

Sampel dalam penelitian ini adalah sebanyak 52 orang pegawai Kantor Camat Asakota Kota Bima. Teknik sampling yang digunakan yaitu sampling jenuh yaitu teknik pengambilan sampel dimana seluruh anggota populasi dijadikan sebagai sampel.

\section{Lokasi Dan Waktu Penelitian}

Penelitian ini dilakukan di Kantor Camat Asakota Kota Bima Jalan Lintas Ule-Kedo.

Waktu penelitian ini dilakukan selama dua bulan yaitu dari bulan desember 2019 sampai bulan januari 2020.

\section{E. Teknik Pengumpulan Data}

Teknik pengumpulan data yang digunakan yaitu :

1. Observasi merupakan teknik pengumpulan data dengan observasi digunakan bila, penelitian berkenaan dengan perilaku manusia, proses kerja, gejala-gejala alam dan bila responden yang diamati tidak terlalu besar

2. Kuisioner merupakan teknik pengumpulan data dengan cara penyebaran angket yang berisi sejumlah pernyataan, dimana setiap jawaban dari pertanyaan tersebut memiliki bobot nilai yang berbeda.

3. Wawancara merupakan Wawancara digunakan sebagai teknik pengumpilan data apabila peneliti ingin melakukan studi pendahuluan untuk mengemukakan permasalahan yang harus diteliti, dan juga apabila peneliti ingin mengetahui hal-hal dari responden yang lebih mendalam dan jumlah respondennya sedikit atau kecil

4. Studi pustaka merupakan tahap yang penting dalam kegiatan penelitian yang merupakan rangkaian proses pengayaan ilmu pengetahuan. Mengingat eratnya keterkaitan antara penelitian dengan pengetahuan yang sudah ada maka dalam melakukan kegiatan penelitian, seorang peneliti harus dekat dengan perpustakaan sebagai gudang ilmu pengetahuan.

\section{F. Jenis Dan Sumber Data}

Jenis Data yang digunakan dalam penelitian ini adalah data kuantitatif yaitu data yang dapat dihitung atau diukur dengan angka, dalam hal ini data berupa tabulasi jawaban responden pada kuisioner yang telah disebarkan.

Sumber Data dalam penelitian ini adalah primer yaitu data yang diperoleh secara langsung dari responden pada objek penelitian.

\section{G. Teknik Analisa Data}

Dalam penelitian ini teknik analisis data yang digunakan antara lain :

1. Uji Validitas adalah sejauh mana ketepatan dan kecermatan suatu alat ukur dalam melakukan fungsi ukurnya (Azwar, 2016: 56). Biasanya syarat minimum untuk dianggap valid dan memenuhi syarat adalah kalau $r=0,300$ atau lebih. Jadi kalau korelasi antara butir dengan skor total kurang dari 0,3 maka dinyatakan tidak valid. 
2. Uji reliabilitas adalah suatu pengujian yang dilakukan untuk mengetahui apakah item-item penyataan dapat dipercaya keakuratannya atau tidak. Syarat untuk menyatakan bahwa butir instrument dinyatakan reliabel biasanya apabila nilai Cronbach's Alfa sama dengan atau lebih besar dari 0,6 (Cronbach's Alfa $\geq 0,6$ ) dan apabila nilainya berada dibawah 0,6 maka dinyatakan tidak reliabel atau kurang dapat dipercaya. (Azwar, 2016: 83).

3. Uji t (t-test one sampel) merupakan uji statistik untuk menguji signifikansi apakah ditemukan untuk semua populasi (Sugiyono, 2016).

Rumus :

$$
\begin{aligned}
t=\frac{\bar{X}-\mu_{o}}{\frac{s}{\sqrt{n}}} \quad \text { Dimana }: \mathrm{t} & =\text { nilai } \mathrm{t} \text { yang di hitung } \\
\overline{\mathrm{X}} & =\text { nilai rata-rata } \\
\mu_{0} & =\text { nilai yang dihipotesiskan } \\
\mathrm{S} & =\text { simpangan baku } \\
\mathrm{n} & =\text { jumlah anggota sampel }
\end{aligned}
$$

\section{HASIL DAN PEMBAHASAN}

\section{A. Uji Validitas}

Tabel 1. : Hasil Uji Validitas

\begin{tabular}{|c|c|c|c|c|}
\hline Variabel & Pernyataan & $\mathrm{r}_{\text {hitung }}$ & $\mathrm{rt}_{\text {abel }}$ & Ket \\
\hline \multirow{4}{*}{$\begin{array}{c}\text { Gaya } \\
\text { Kepemimpinan }\end{array}$} & Item 1 & 0,550 & 0,300 & Valid \\
\cline { 2 - 5 } & Item 2 & 0,598 & 0,300 & Valid \\
\cline { 2 - 5 } & Item 3 & 0,395 & 0,300 & Valid \\
\cline { 2 - 5 } & Item 4 & 0,543 & 0,300 & Valid \\
\cline { 2 - 5 } & Item 5 & 0,616 & 0,300 & Valid \\
\cline { 2 - 5 } & Item 6 & 0,509 & 0,300 & Valid \\
\cline { 2 - 5 } & Item 7 & 0,436 & 0,300 & Valid \\
\cline { 2 - 5 } & Item 8 & 0,665 & 0,300 & Valid \\
\hline
\end{tabular}

Sumber : Data Primer Diolah, 2020

Berdasarkan tabel 1 di atas, hasil pengujian validitas terhadap variabel Gaya kepemimpinan dapat dikatakan semua item pernyataan yang diajukan adalah valid karena berada diatas standar validitas yaitu $\geq 0,300$

\section{B. Uji Reliabilitas}

Tabel 2. : Hasil Uji Reliabilitas

\begin{tabular}{|c|c|c|c|}
\hline Variabel & Cronbach's alpha & Standar & Ket \\
\hline Gaya Kepemimpinan & 0,647 & 0,6 & Reliabel \\
\hline
\end{tabular}

Hasil uji reliabilitas terhadap item pernyataan pada variabel Gaya kepemimpinan dengan nilai cronbach's Alpha yang didapat 0,647 sudah mencapai atau lebih dari standar yang ditetapkan yaitu 0,6 artinya semua item pernyataan dari kuisioner dinyatakan reliabel atau akurat untuk digunakan dalam perhitungan penelitian.

\section{Uji t (t-test one sampel)}

Untuk menganalisa permasalahan dan menguji hipotesis di dalam penelitian ini maka digunakan data hasil kuisioner yang disebarkan kepada 52 orang pegawai Kantor Camat 
Asakota Kota Bima, selanjutnya data tersebut di analisa secara statistik dengan menggunakan uji t-test one sampel dan dengan bantuan SPSS.

Menurut Sugiyono (2016), untuk penelitian deskriptif terlebih dahulu di cari nilai skor ideal dan rata-rata dari variabel yang diteliti untuk mendapatkan nilai yang dihipotesiskan $\left(\mu_{0}\right)$ sebagai berikut :

Skor ideal $=$ skor tertinggi kuisioner $\mathrm{x}$ jumlah item pernyataan $\mathrm{x}$ jumlah responden

$$
=5 \times 8 \times 52=2080
$$

Rata-rata $=$ Skor ideal : jumlah responden

$$
=2080: 52=40
$$

$\mu_{0}=70 \%=0,7 \times$ Rata - rata $=0,7 \times 40=28$

Untuk $\mathrm{n}=52$ dan $\bar{X}=34,192$, diperoleh nilai $\quad \sum(X-\bar{X})^{2}=258,077$

Perhitungan nilai standar deviasi (simpangan baku) sebagai berikut :

$$
s=\sqrt{\frac{(\mathrm{X}-\overline{\mathrm{X}})^{2}}{n-1}} \text { diperoleh nilai } s=2,249518466990954
$$

Selanjutnya perhitungan $t$-test one sampel sebagai berikut :

$$
\begin{aligned}
& t=\frac{\bar{X}-\mu_{o}}{\frac{s}{\sqrt{n}}} \\
& t=\frac{34,192-28}{\frac{2,249518466990954}{\sqrt{52}}} ; t=19,849
\end{aligned}
$$

\begin{tabular}{|c|c|c|c|c|c|c|}
\hline & \multicolumn{6}{|c|}{ Test Value $=31.5$} \\
\hline & \multirow[t]{2}{*}{$\bar{T}$} & \multirow[t]{2}{*}{$\overline{D f}$} & \multirow[t]{2}{*}{$\begin{array}{l}\text { Sig. (2- } \\
\text { tailed) }\end{array}$} & \multirow[t]{2}{*}{$\begin{array}{c}\text { Mean } \\
\text { Difference }\end{array}$} & \multicolumn{2}{|c|}{$\begin{array}{l}95 \% \text { Confidence } \\
\text { Interval of the } \\
\text { Difference }\end{array}$} \\
\hline & & & & & Lower & Upper \\
\hline $\begin{array}{c}\text { Gaya } \\
\text { Kepemimpinan }\end{array}$ & 19,850 & 51 &, 000 & 6,19231 & 5,5660 & 6,8186 \\
\hline
\end{tabular}

Jika perhitungan $t$-test one sampel dengan bantuan program SPSS, diperoleh hasil seperti Tabel 3 sebagai berikut :

Tabel 3. : Hasil perhitungan Uji t

Une-Sample I est

Jadi nilai t hitung dari SPSS adalah sebesar 19,850. Kemudian nilai t hitung dari SPSS tersebut akan dibandingkan dengan $\mathrm{t}$ tabel dengan derajat kebebasan $(\mathrm{dk})=\mathrm{n}-1=52-1=$ 51 , dan taraf kesalahan $5 \%(0,05)$ untuk uji satu pihak yaitu pihak kanan maka di dapat nilai $\mathrm{t}$ tabel adalah sebesar 1,675.

\section{Ketentuan penerimaan dan penolakan hipotesis Uji satu pihak kanan:}

Jika $t_{\text {hitung }}$ lebih kecil dari $t_{\text {tabel }}\left(t_{\text {hitung }}<t_{\text {tabel }}\right.$ ) maka $\mathrm{H}_{0}$ diterima dan $\mathrm{H}_{\mathrm{a}}$ ditolak, sedangkan nilai koefisien signifikansinya lebih kecil dari 0.05 (Sig < 0,05) maka dinyatakan signifikan (Sugiyono, 2016).

Jika di bandingkan antara nilai $t_{\text {hitung }}$ dengan $t_{\text {tabel }}$, maka $t_{\text {hitung }}$ lebih besar dari $t_{\text {tabel }}$ $(19,850>1,675)$, dan nilai Sig $<0,05(0,000<0,05)$ ini berarti $\mathbf{H}_{\mathbf{a}}$ diterima dan $\mathbf{H}_{\mathbf{0}}$ ditolak.

Jadi dapat disimpulkan pada hipotesis yang diterima adalah hipotesis alternatif $\left(\mathrm{H}_{\mathrm{a}}\right)$ yang menyatakan bahwa Gaya Kepemimpinan pada Kantor Camat Asakota Kota Bima lebih dari atau sama dengan $70 \%$ dari yang diharapkan (baik) dapat diterima. 


\section{KESIMPULAN DAN SARAN}

\section{A. Kesimpulan}

Berdasarkan hasil analisis tersebut di atas maka dapat kami simpulkan bahwa Gaya Kepemimpinan pada Kantor Camat Asakota Kota Bima masuk dapat diterima oleh masyarakat di kecamatan Asakota Kota Bima.

\section{B. Saran}

1. Disarankan pada Kantor Camat Asakota Kota Bima untuk terus meningkatkan atau setidaknya mempertahankan Gaya kepemimpinan yang selama ini diterapkan agar apa yang menjadi tujuan organisasi dapat tercapai karena terbukti dari penelitian yang dilakukan diperoleh hasil bahwa pegawai patuh dan taat pada pimpinan dengan gaya kepemimpinan yang ada selama ini.

2. Bagi peneliti selanjutnya diharapkan dapat menyempurnakan penelitian yang ada, dan terus mengembangkan variabel-variabel baru untuk diteliti sehingga menjadi tambahan referensi bagi kemajuan ilmu pengetahuan khususnya di bidang penelitian SDM.

\section{DAFTAR PUSTAKA}

Azwar, Saifuddin. 2016. Metode Penelitian. Yogyakarta : Pustaka Pelajar

Bambang, Wahyudi. 2012. Manajemen Sumber Daya Manusia. Bandung : Sulita.

Bambang, Guritno dan Waridin (2005). Pengaruh Persepsi Karyawan Mengenai Perilaku Kepemimpinan, Kepuasan Kerja Dan Motivasi Terhadap Kinerja. JRBI, 1 (1) : 63-74.

Bangun, Wilson. 2012. Manajemen Sumber Daya Manusia. Jakarta : Erlangga

Davis, Keith dan John W. Newstrom. 2012. Perilaku Dalam Organisasi. Jakarta : Erlangga

Fandy Tjiptono dan Gregorius Chandra. 2016. Service, Quality \& Satisfaction. Yogyakarta ; Andi.

Nawawi, Ismail. 2013. Budaya organisasi kepemimpinan dan Kinerja. Jakarta: PT. Fajar. Iterpratama Mandiri.

Robbins, S. 2012. Perilaku Organisasi. Jakarta : Salemba Empat.

Winardi. 2016. Kepemimpinan dalam Manajemen. Jakarta : PT. Rineka Cipta 